\title{
Interobserver Agreement Among Histological Patterns and Diagnosis in Lung Adenocarcinomas
}

\author{
Akciğer Adenokarsinomunda, Histolojik Patern ve Tanıda \\ Kişiler Arası Uyum Değerlendirmesi
}

\author{
Halide Nur ÜRER ${ }^{1}$, Rengin AHISKALI ${ }^{2}$, Naciye ARDA ${ }^{1}$, Sebnem BATUR ${ }^{3}$, Leyla CINEL ${ }^{4}$, \\ Gerhard DEKAN ${ }^{5}$, Neslihan FENER ${ }^{1}$, Pınar FIRAT ${ }^{6}$, Silvana GELEFF ${ }^{5}$, Büge ÖZ ${ }^{3}$, Yasemin ÖZLÜK ${ }^{6}$, \\ Kürşat YILDIZ7 , Emine Dilek YILMAZBAYHAN ${ }^{6}$, Handan ZEREN ${ }^{8}$, Atilla UYSAL ${ }^{9}$
}

Departments of ${ }^{1}$ Pathology and ${ }^{9}$ Chest Diseases, Yedikule Chest Diseases and Chest Surgery Education and Research Hospital, iSTANBUL, TURKEY Department of Pathology, ${ }^{2}$ Marmara University, Faculty of Medicine, ISTANBUL, TURKEY, ${ }^{3}$ stanbul University, Cerrahpaşa Medicine Faculty, iSTANBUL, TURKEY, ${ }^{4}$ Ministry of Health Istanbul Medeniyet University, ISTANBUL, TURKEY, ${ }^{5}$ Medical University of Vienna, VIENNA, AUSTRIA, ${ }^{6}$ Istanbul University, Istanbul Medicine Faculty, iSTANBUL, TURKEY, ${ }^{7}$ Kocaeli University, Faculty of Medicine, ISTANBUL, TURKEY, ${ }^{8}$ Acibadem University, Faculty of Medicine, ISTANBUL, TURKEY

\begin{abstract}
Objective: The aim of this study was to investigate the interobserver agreement in determination of the dominant histological pattern and the final diagnosis in lung adenocarcinomas.
\end{abstract}

Material and Method: A total of 12 patients with a diagnosis of primary lung adenocarcinoma were included in the study. Twelve pathologists from eight study centers were asked first to determine the dominant histological pattern in these cases and then to decide whether the final diagnosis was in situ, minimally invasive or invasive adenocarcinoma.

Results: The kappa value for the agreement in determining the dominant pattern among the pathologists was $0.36(\mathrm{p}<0.001)$, with the values for the lepidic, acinar, papillary, solid, micropapillary patterns and mucinous character of adenocarcinoma being $0.34,0.28$, $0.30,0.80,0.16$ and 0.38 respectively $(\mathrm{p}<0.001, \mathrm{p}<0.001, \mathrm{p}<0.001$, $\mathrm{p}<0.001, \mathrm{p}<0.001, \mathrm{p}<0.001)$. None of the cases was diagnosed as in situ adenocarcinoma. On the other hand, the kappa value for the agreement in differentiating minimally invasive from invasive adenocarcinoma among reviewers was $0.17(\mathrm{p}<0.001)$.

Conclusion: The agreement among pathologists in determining the subtype of lung adenocarcinomas that depends on the identification of the dominant pattern was at intermediate level. In addition, the agreement in deciding whether the case is minimally invasive or invasive, was at low level. The criteria defining the histological patterns should be clarified and described in more detail. Educational activities and larger multicenter studies might be helpful in improving the agreement and standardization.

Key Words: Adenocarcinoma, Lung neoplasms, Interobserver variations

\section{ÖZ}

Amaç: $\mathrm{Bu}$ çalışmanın amacı, akciğer adenokarsinomunda baskın histolojik patern belirlemede ve nihai tanı konusunda değerlendiriciler arası uyumun araştırılmasıdır.

Gereç ve Yöntem: Komplet cerrahi rezeksiyon uygulanan ve mikst tipte primer akciğer adenokarsinom tanılı 12 olgu çalışmaya alındı. Çalışma sekiz merkezden 12 patologun katılımı ile yapıldı. Değerlendiricilerden baskın patern tayini ile son tanı olarak invaziv adenokarsinom, minimal invaziv adenokarsinom arasında seçim yapmaları istendi.

Bulgular: Patologlar arasında baskın patern uyumunda kappa değeri 0.36 idi. Lepidik, asiner, papiller, solid, mikropapiller ve musinöz paternde uyum sirasiyla $0,34,0,28,0,30,0,80,0,16,0,38(\mathrm{p}<0,001$, $\mathrm{p}<0,001, \mathrm{p}<0,001, \mathrm{p}<0,001, \mathrm{p}<0,001, \mathrm{p}<0,001)$ idi. Hiçbir olgu in situ adenokarsinom tanısı almadı. Minimal invaziv adenokarsinom ve invaziv adenokarsinom tanısı için değerlendiriciler arasındaki uyum düşüktü (kappa değeri 0,17 ( $\mathrm{p}<0,001)$ ).

Sonuç: Patologlar arası akciğer adenokarsinomunu baskın patern saptamasında uyum orta düzeyde bulundu. Minimal invaziv adenokarsinom ile İAK arası uyum ise düşük düzeyde idi. Histolojik patern kriterleri daha açık ve daha detaylı olarak tanımlanmalıdır. Eğitim programları ve çok merkezli çalışmalar tanıların standardizasyon ve uyumunu geliştirilebilir.

Anahtar Sözcükler: Adenokarsinom, Akciğer tümörleri, Gözlemci değişkenliği
(Turk Patoloji Derg 2014, 30:105-110)

Received : 20.11.2013 Accepted : 08.01.2014
Correspondence: Halide Nur URER

Yedikule Göğüs Hastalıkları ve Gögüs Cerrahisi Eğitim ve Araştırma

Hastanesi, Patoloji Kliniği, İSTANBUL, TURKEY

E-mail: nururer@yahoo.com Phone: +90 5052659365 


\section{INTRODUCTION}

Lung adenocarcinomas (ACs) are different from other organ ACs due to the presence of heterogeneous tumors with morphological diversity (1). The coexistence of more than one histological pattern (mixed-type) is observed in $80-90 \%$ of tumors, and determining the dominant pattern in the tumor is important in terms of disease prognosis $(2,3,4)$. According to the 2011 consensus report of the International Association for the Study of Lung Cancer, American Thoracic Society and the European Respiratory Society (IASLC/ATS/ERS), identifying the dominant pattern as well as other histological patterns in AC along

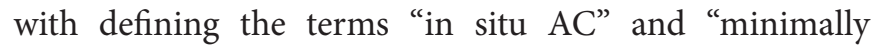
invasive $\mathrm{AC}$ " were important prognostic and predictive factors (Table I) (5). Moreover, the various studies have highlighted the prognostic importance of the new AC classification system $(6,7)$.

In this study, we aimed to investigate the interobserver agreement in terms of the dominant histological AC pattern and final diagnosis of AC.

\section{MATERIAL and METHODS}

A total of 12 patients with a diagnosis of primary lung AC who underwent a complete surgical resection were randomly selected from the archives of the pathology department of Yedikule Chest Diseases and Chest Surgery Education and Research Hospital. In all cases, the tumors were located outside of the bronchi in the peripheral parenchyma. The largest tumor diameter was 3 centimeters, with a median of 1.9 centimeters (range 1-2.5). For the most widespread representation of tumors in each case, sets consisting of three glass slides originating from one or two paraffin blocks were prepared and stained with H\&E, PAS, and Elastica Van Gieson.

The study included a total of 12 pathologists from eight institutions who specialized in lung pathology. The samples were evaluated under light microscopy according to the histologic criteria specified in the 2011 IASLC/ATS/ ERS international multidisciplinary classification of lung adenocarcinoma consensus (5). The reviewers were asked to determine the dominant $\mathrm{AC}$ pattern, presence of mucinous character and final diagnosis in each case. Adenocarcinoma patterns were lepidic, acinar, papillary, solid, micropapillary as described in the IASLC/ATS/ERS report. They were also asked to decide whether the case is a minimally invasive adenocarcinoma (MIAC) or an invasive adenocarcinoma (IAC) according to the morphology and the diameter of the invasive focus.
To determine the interobserver agreement among dominant patterns (lepidic, acinar, papillary, solid, micropapillary and mucinous), and between IAC and MIAC the results were evaluated using Fleiss kappa statistics (StataCorp. 2011, Stata Statistical Software: Release 12, College Station, TX, USA, StataCorp LP). The meaning of kappa values representing agreement among observers is presented in Table II (8).

Table I: *IASLC/ATS/ERS Classification of Lung Adenocarcinoma

Preinvasive lesions

Atypical adenomatous hyperplasia

Adenocarcinoma in situ $(\leq 3 \mathrm{~cm}$, pure lepidic growth lacking invasion)

Non-mucinous/Mucinous/mixed

Minimally invasive adenocarcinoma $(\leq 3 \mathrm{~cm}$ lepidic predominant tumor with $\leq 5 \mathrm{~mm}$ invasion)

Non-mucinous/Mucinous/Mixed.

Invasive adenocarcinoma

Lepidic predominant

Acinar predominant

Papillary predominant

Micropapillary predominant

Solid predominant with mucin production

Variants of invasive adenocarcinoma

Invasive mucinous adenocarcinoma

Colloid

Fetal (low and high grade)

Enteric

* "IASLC" International Association for the Study of Lung Cancer. "ATS" American Thoracic Society. "ERS" European Respiratory Society.

Table II: Kappa values for the levels of agreement

\begin{tabular}{|l|c|}
\hline Kappa & Agreement Level \\
\hline 0 & None \\
$0-0.20$ & Weak \\
$0.21-0.40$ & Intermediate \\
$0.41-0.60$ & Moderate \\
$0.61-0.80$ & Good \\
$0.81-1$ & Perfect \\
\hline
\end{tabular}




\section{RESULTS}

A total of 144 diagnoses were made in 12 cases by 12 reviewers. Of the 144 diagnoses, 117 were IAC and 27 were MIAC (Figure 1). In only three cases, over $80 \%$ agreement were obtained with two different histologic patterns. In three cases, over $70 \%$ agreement were obtained with the three different histologic patterns. The other six cases (50\%) showed $<70 \%$ agreement with $\geq 3$ histologic patterns (Figure 2A-D, 3). The agreement for the dominant patterns among reviewers was intermediate level (kappa $=0.36$; $\mathrm{p}<0.001)$, and the kappa values for the histological lepidic, acinar, papillary, solid, micropapillary patterns and mucinous character were $0.34,0.28,0.30,0.80,0.16$, and 0.38 , respectively $(\mathrm{p}<0.001)$ (Table III).

The agreement in establishing stromal invasion was 100\% and none of the cases were diagnosed as in situ AC. However, the agreement for the IAC and MIAC among reviewers was low level $(k a p p a=0.17 ; \mathrm{p}<0.001)$.

\section{DISCUSSION}

In the lung tumors classification of World Health Organisation (WHO), ACs with heterogeneous histology has been put together under the category of "mixedtype" (1). Recent regulations in the lung adenocarcinoma classification have led to some changes in terms of histopathological approach and diagnosis, all of which affect disease prognosis (5). Thus, the diagnosis of "mixed adenocarcinoma" was replaced with "dominant pattern adenocarcinoma", and the concepts of "minimally invasive" and "in situ" were included in the differential diagnosis for tumors with a diameter of $3 \mathrm{~cm}$ or less. Invasion is
Table III: Kappa values of the histological patterns

\begin{tabular}{|l|c|c|}
\hline Pattern & Kappa value & P value \\
\hline Lepidic & 0.34 & $\mathrm{P}<0.001$ \\
\hline Acinar & 0.28 & $\mathrm{P}<0.001$ \\
\hline Papillary & 0.30 & $\mathrm{P}<0.001$ \\
\hline Solid & 0.80 & $\mathrm{P}<0.001$ \\
\hline Micropapillary & 0.16 & $\mathrm{P}<0.001$ \\
\hline Mucinous & 0.38 & $\mathrm{P}<0.001$ \\
\hline Overall & 0.36 & $\mathrm{P}<0.001$ \\
\hline
\end{tabular}

described as tumor cells infiltrating the myofibroblastic stroma or presence of any histological pattern other than lepidic. Furthermore, "invasive mucinous adenocarcinoma" was defined as a variant that includes most of the former mucinous-type bronchioloalveolar adenocarcinomas (5).

Various studies exist that have discussed relatively high reproducibility of histological subtyping of lung ACs (9, 10). However, there are also some other studies suggesting that the level of agreement is low for determining subtypes because of differentiation and the complex heterogeneous framework $(11,12)$. The main reason for this lies in the interlaced lepidic, acinar, and papillary patterns in the absence of desmoplasia. In addition, differentiating micropapillary and lepidic patterns from papillary may also be problematic; the classification requires that lepidic growth in the alveolar space filled with papillary structures should be considered as papillary AC in the absence of myofibroblastic stroma $(5,13)$. These studies suggest that the differential diagnosis of the patterns (especially lepidic,

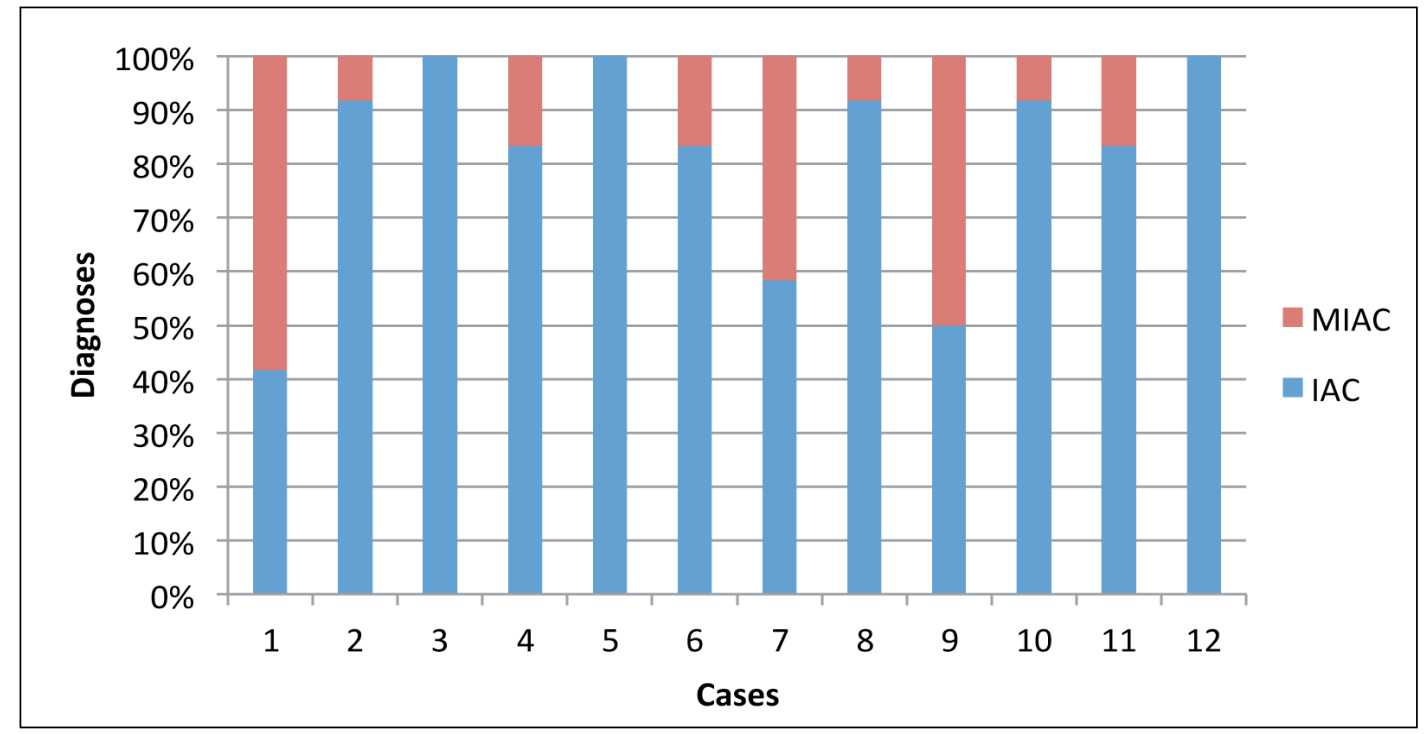

Figure 1: The distribution of adenocarcinoma diagnoses. 

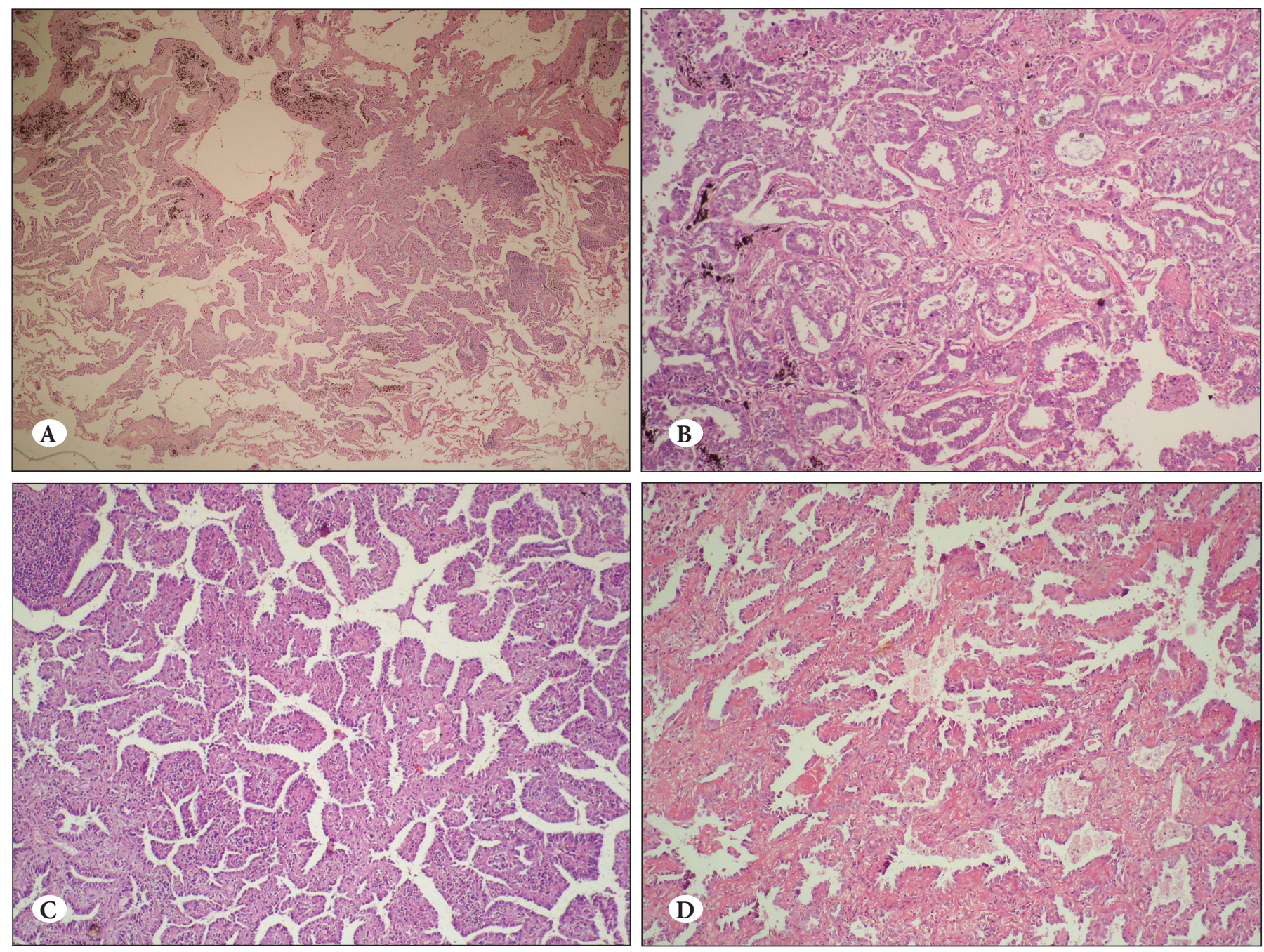

Figure 2: A) Lepidic pattern (H\&E; x40), B) Acinar pattern (H\&E; x200), C) Papillary pattern (H\&E; x100), D) Lepidic and acinar pattern (H\&E; x100).

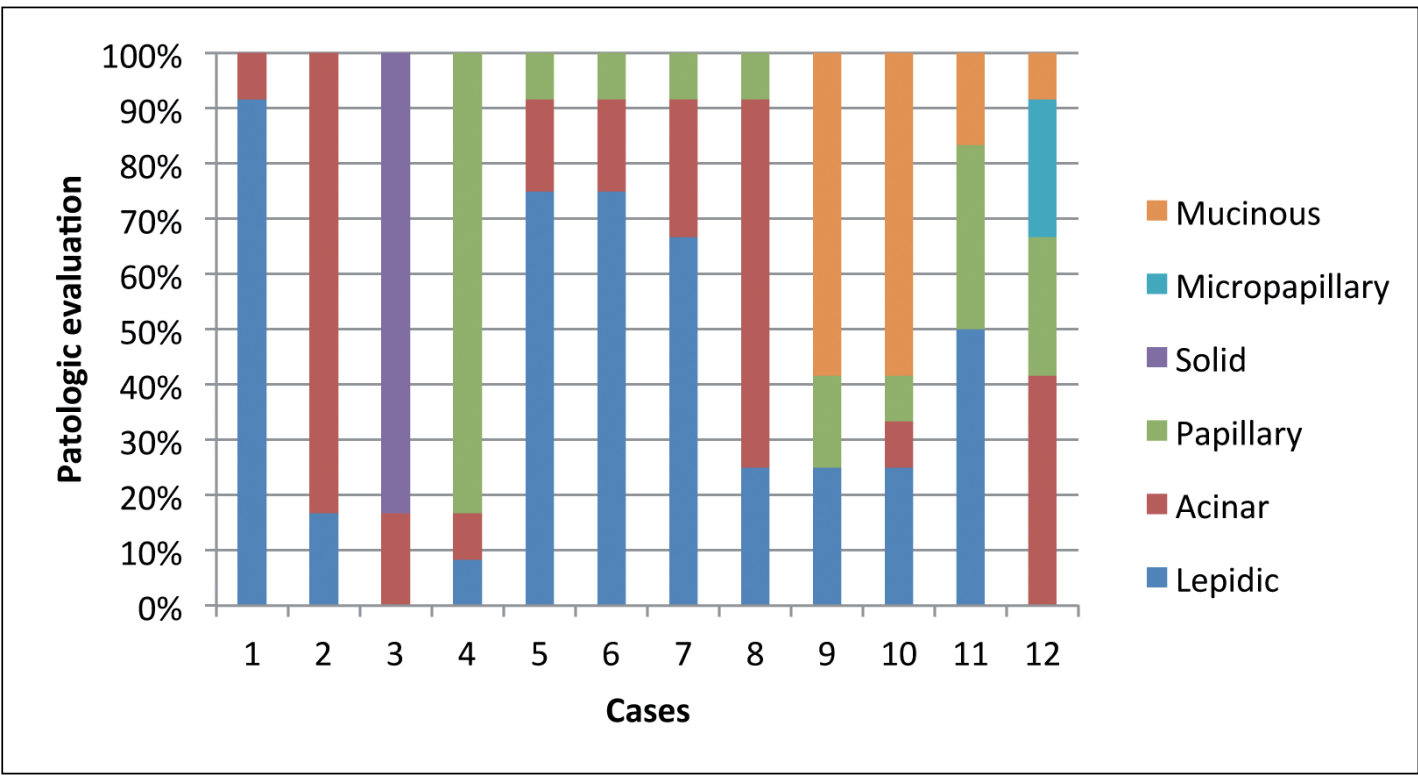

Figure 3: The dominant histological patterns in the cases. 
acinar and papillary) is still open to discussion. On the other hand, the solid pattern, which consists of lined-up tumor cells without a definite frame and space, shows the highest rate of agreement (14). In the present study, weak and intermediate agreement was detected in patterns other than the solid subtype; our results were similar to other studies. Noguchi and Warth reported that education programs performed with the assistance of experienced pathologists have increased the agreement. However, the fact that their results did not reach perfect levels indicates that further studies are needed involving larger series with non-randomized cases $(14,15)$.

Our study showed that the level of agreement in differentiating IAC form MIAC is low. Not only detecting the cells invading the stroma individually but also presence of any pattern other than lepidic defines invasion (5). As explained above, when there is no desmoplasia due to the difficulty in differentiating patterns, measuring the magnitude of invasive focus under this complex frame is technically challenging (16).

The main limitation of our study was the low number of cases. In addition, the selected cases were indeed difficult to subtype. In studies performed on tumors with typical morphology, high levels of agreement were reported when compared with the agreement rates in problematic cases (9). Furthermore, the study was of a single-step design and had no reference pathologist.

When determining the subtype of lung ACs in this study, we observed an intermediate level of agreement in identifying different patterns and a weak level of agreement in the diagnosis of MIAC. Our findings indicate that further studies are necessary and the classification criteria should be described in more detail to clarify some possible miscategorizations that currently exist. Educational activities and larger multicenter studies might be helpful for standardization.

\section{REFERENCES}

1. Travis WD, Brambilla E, Muller-Hermelink HK, Harris CC. World Health Organization Classification of tumours. Pathology and genetics. Tumours of the lung, pleura, thymus and heart. Lyon: IARC Press; 2004.35-40.

2. Travis WD, Garg K, Franklin WA, Wistuba II, Sabloff B, Noguchi M, Kakinuma R, Zakowski M, Ginsberg M, Padera R, Jacobson F, Johnson BE, Hirsch F, Brambilla E, Flieder DB, Geisinger KR, Thunnissen F, Kerr K, Yankelevitz D, Franks TJ, Galvin JR, Henderson DW, Nicholson AG, Hasleton PS, Roggli V, Tsao MS, Cappuzzo F, Vazquez M. Bronchioloalveolar carcinoma and lung adenocarcinoma: The clinical importance and research relevance of the 2004 World Health Organization pathologic criteria. J Thorac Oncol. 2006;1:13-9.
3. Motoi N, Szoke J, Riely GJ, Seshan VE, Kris MG, Rusch VW, Gerald WL, Travis WD. Lung adenocarcinoma: Modification of the 2004 WHO mixed subtype to include the major histologic subtype suggests correlations between papillary and micropapillary adenocarcinoma subtypes, EGFR mutations and gene expression analysis. Am J Surg Pathol. 2008;32:810-27.

4. Yoshizawa A, Motoi N, Riely GJ, Sima CS, Gerald WL, Kris MG, Park BJ, Rusch VW, Travis WD. Impact of proposed IASLC/ATS/ ERS classification of lung adenocarcinoma: Prognostic subgroups and implications for further revised of staging based on analysis of 514 stage I cases. Mod Pathol. 2011;24:653-64.

5. Travis WD, Brambilla E, Noguchi M, Nicholson AG, Geisinger KR, Yatabe Y, Beer DG, Powell CA, Riely GJ, Van Schil PE, Garg K, Austin JH, Asamura H, Rusch VW, Hirsch FR, Scagliotti G, Mitsudomi T, Huber RM, Ishikawa Y, Jett J, Sanchez-Cespedes M, Sculier JP, Takahashi T, Tsuboi M, Vansteenkiste J, Wistuba I, Yang PC, Aberle D, Brambilla C, Flieder D, Franklin W, Gazdar A, Gould M, Hasleton P, Henderson D, Johnson B, Johnson D, Kerr K, Kuriyama K, Lee JS, Miller VA, Petersen I, Roggli V, Rosell R, Saijo N, Thunnissen E, Tsao M, Yankelewitz D. International Association for the Study of Lung Cancer/American Thoracic Society/European Respiratory Society International Multidisciplinary Classification of Lung Adenocarcinoma. J Thorac Oncol. 2011;6:244-85.

6. Kerr KM. Clinical relevance of the new IASLC/ERS/ATS adenocarcinoma classification. J Clin Pathol. 2013;66:832-8.

7. Yanagawa N, Shiono S, Abiko M, Ogata SY, Sato T, Tamura G. New IASLC/ATS/ERS classification and invasive tumor size are predictive of disease recurrence in stage I lung adenocarcinoma. J Thorac Oncol. 2013;8:612-8.

8. Landis JR, Koch GG. The measurement of observer agreement for categorical data. Biometrics. 1977;33:159-74.

9. Thunnissen E, Beasley MB, Borczuk AC, Brambilla E, Chirieac LR, Dacic S, Flieder D, Gazdar A, Geisinger K, Hasleton P, Ishikawa Y, Kerr KM, Lantejoul S, Matsuno Y, Minami Y, Moreira AL, Motoi N, Nicholson AG, Noguchi M, Nonaka D, Pelosi G, Petersen I, Rekhtman N, Roggli V, Travis WD, Tsao MS, Wistuba I, Xu H, Yatabe Y, Zakowski M, Witte B, Kuik DJ. Reproducibility of histopathological subtypes and invasion in pulmonary adenocarcinoma. An international interobserver study. Mod Pathol. 2012;25:1574-83.

10. Warth A, Stenzinger A, von Brünneck AC, Goeppert B, Cortis J, Petersen I, Hoffmann H, Schnabel PA, Weichert W. Interobserver variability in the application of the novel IASLC/ATS/ERS classification for pulmonary adenocarcinomas. Eur Respir J. 2012;40:1221-7.

11. Sørensen JB, Hirsch FR, Gazdar A, Olsen JE. Interobserver variability in histopathologic subtyping and grading of pulmonary adenocarcinoma. Cancer. 1993;71:2971-6.

12. Chilosi M, Murer B. Mixed adenocarcinomas of the lung: Place in new proposals in classification, mandatory for target therapy. Arch Pathol Lab Med. 2010;134:55-65.

13. Keith M Kerr. Pulmonary adenocarcinomas: Classification and reporting. Histopathology. 2009;54:12-27. 
14. Noguchi M, Minami Y, Iijima T, Matsuno Y. Reproducibility of the diagnosis of small adenocarcinoma of the lung and usefulness of an educational program for the diagnostic criteria. Pathol Int. 2005;55:8-13.

15. Warth A, Cortis J, Fink L, Fisseler-Eckhoff A, Geddert H, Hager T, Junker K, Kayser G, Kitz J, Länger F, Morresi-Hauf A, Ott G, Petersen I, Stenzinger A, Soltermann A, Ting S, Tischler V, Vollmer E, Schnabel PA, Weichert W; Pulmonary Pathology Working Group of the German Society of Pathology. Training increases concordance in classifying pulmonary adenocarcinomas according to the novel IASLC/ATS/ERS classification. Virchows Arch. 2012;461:185-93.

16. Xu L, Tavora F, Battafarano R, Burke A. Adenocarcinomas with prominent lepidic spread: Retrospective review applying new classification of the American Thoracic Society. Am J Surg Pathol. 2012;36:273-82. 